\section{IDEVIIIFIKASI LAHAM TERBEMMAR LOEMM BERAT PADA TANAH SAWAH}

Tanah sawah merupakan tanah yang sangat penting di Indonesia karena merupakan sumber daya alam yang utama untuk membudidayakan tanaman padi dalam memproduksi beras. Permasalahan utama pada budidaya padi di lahan sawah adalah terjadinya pencemaran tanah akibat adanya kawasan industri yang semakin berkembang. Pengelolaan sawah secara intensif diperlukan untuk mengatasi permasalahan tersebut. Buku ini membahas tentang bagaimana mengevaluasi sebaran pencemaran logam berat dari pembuangan limbah pabrik tekstil serta mengidentifikasi percemaran kandungan logam berat tersebut terhadap kandungan unsur hara $\mathrm{N}, \mathrm{C}$-organik dan $\mathrm{pH}$ tanah pada tanah sawah.
Leony Agustine

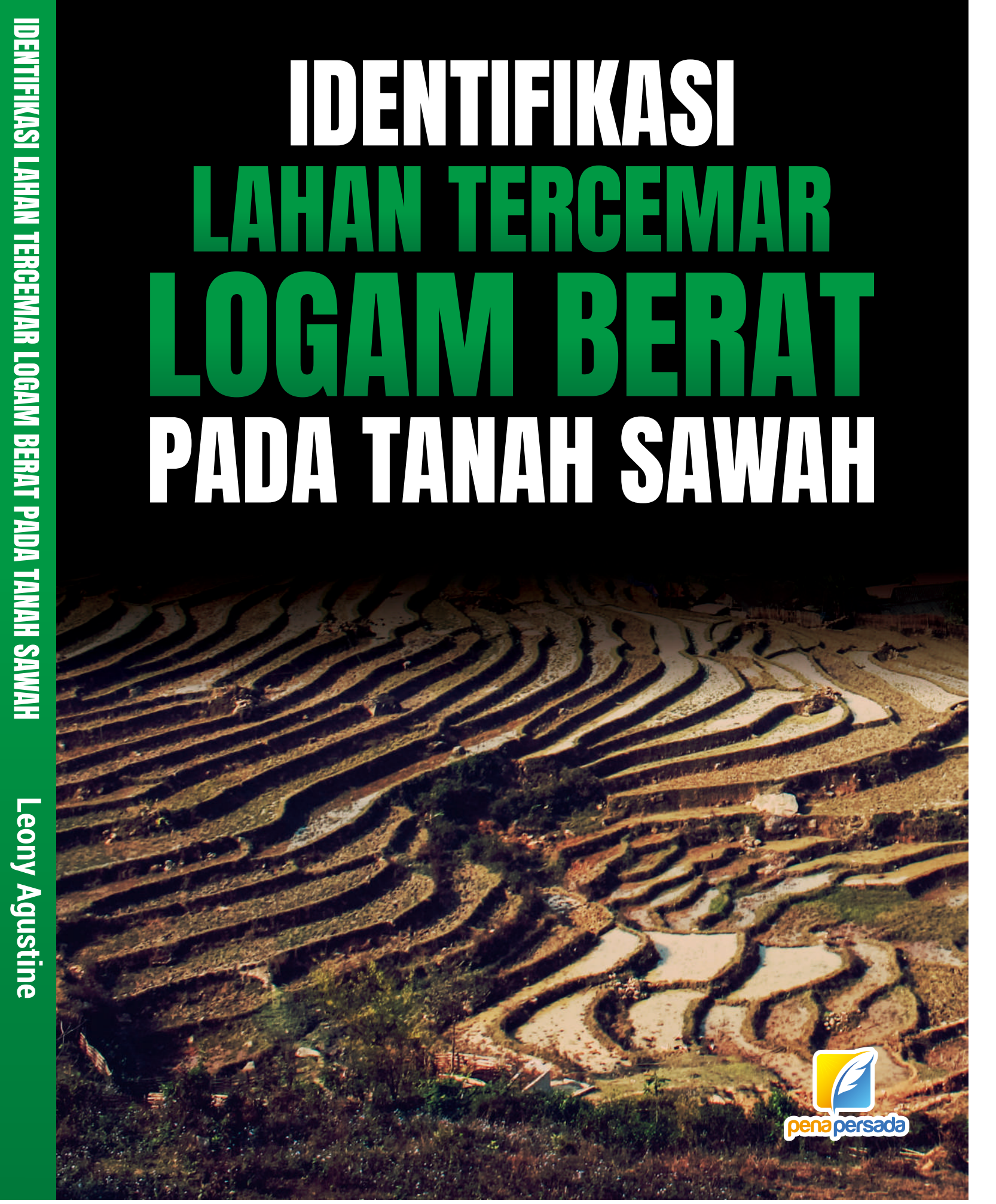




\title{
IDENTIFIKASI LAHAN TERCEMAR LOGAM BERAT PADA TANAH SAWAH
}

\author{
LEONY AGUSTINE
}

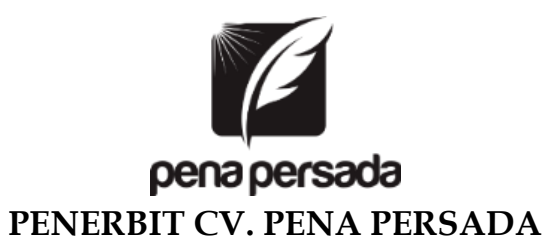




\title{
IDENTIFIKASI LAHAN TERCEMAR LOGAM BERAT PADA TANAH SAWAH
}

\author{
Penulis: \\ Leony Agustine \\ ISBN : 978-623-315-509-0 \\ Editor: \\ Wiwit Kurniawan \\ Design Cover : \\ Retnani Nur Briliant
}

Layout :

Eka Safitry

\section{Penerbit CV. Pena Persada \\ Redaksi :}

Jl. Gerilya No. 292 Purwokerto Selatan, Kab. Banyumas

Jawa Tengah

Email : penerbit.penapersada@gmail.com

Website : penapersada.com Phone : (0281) 7771388

Anggota IKAPI

All right reserved

Cetakan pertama : 2021

Hak Cipta dilindungi oleh undang-undang. Dilarang memperbanyak karya tulis ini dalam bentuk apapun tanpa izin penerbit 


\section{KATA PENGANTAR}

Puji syukur saya panjatkan kepada Tuhan Yang Maha Esa, karena atas berkat dan rahmat-Nya, saya dapat menyelesaikan buku ini. Penulisan buku merupakan buah karya dari pemikiran penulis yang diberi judul " IDENTIFIKASI LAHAN TERCEMAR LOGAM BERAT PADA TANAH SAWAH". Saya menyadari bahwa tanpa bantuan dan bimbingan dari berbagai pihak sangatlah sulit bagi saya untuk menyelesaikan karya ini. Oleh karena itu, saya mengucapkan banyak terima kasih pada semua pihak yang telah membantu penyusunan buku ini. Sehingga buku ini bisa hadir di hadapan pembaca.

Permasalahan utama pada budidaya padi di lahan sawah adalah terjadinya pencemaran tanah akibat adanya kawasan industri yang semakin berkembang. Pengelolaan sawah secara intensif diperlukan untuk mengatasi permasalahan tersebut, salah satunya melalui pemahaman ketersediaan hara. Salah satu unsur hara yang diperlukan tanaman diantaranya adalah unsur hara $\mathrm{N}$, sehingga perlu pengkajian kandungan unsur hara $\mathrm{N}$ agar dicapai pemupukan yang efektif dan efisien, sehingga mampu memberikan produksi yang optimal dan menguntungkan bagi petani. Ada beberapa pemabahasan dalam buku ini, yaitu: 1) mengevaluasi sebaran pencemaran logam berat dari pembuangan limbah pabrik tekstil terhadap areal persawahan padi di Kecamatan Rancaekek, 2) mengkaji kandungan logam berat, unsur hara N, C-organik dan $\mathrm{pH}$ tanah yang terdapat pada tanah areal persawahan padi di Kecamatan Rancaekek, 3) mengidentifikasi percemaran kandungan logam berat terhadap kandungan unsur hara $\mathrm{N}, \mathrm{C}$-organik dan $\mathrm{pH}$ tanah.

Penulis menyadari bahwa buku ini masih jauh dari kesempurnaan. Oleh karena itu kritik dan saran yang membangun sangat dibutuhkan guna penyempurnaan buku ini. Akhir kata saya berharap Tuhan Yang Maha Esa berkenan membalas segala kebaikan semua pihak yang telah membantu.

Penulis 


\section{DAFTAR ISI}

KATA PENGANTAR ....................................................................ii

DAFTAR ISI ................................................................................. iv

BAB I PENDAHULUAN ............................................................... 1

A. Penggunaan Lahan Sawah ........................................... 1

B. Kandungan Logam Berat Lahan Sawah ............................ 2

C. Metode Analisis ................................................................... 3

1. Tempat dan Waktu .................................................... 3

2. Bahan dan Alat ............................................................... 4

3. Metode ............................................................................ 4

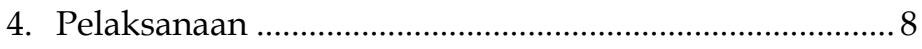

BAB II DESKRIPSI LAHAN SAWAH ......................................... 10

A. Jenis Tanah.................................................................. 10

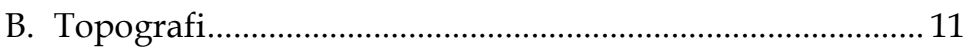

C. Penggunaan Lahan .......................................................... 13

BAB III KONSENTRASI UNSUR PENDUKUNG ........................ 17

A. N Total.......................................................................... 17

B. $\mathrm{pH}$ Tanah .............................................................................. 19

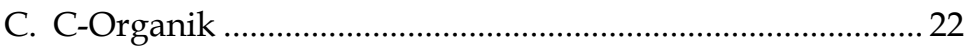

BAB IV KONSENTRASI LOGAM BERAT ..................................... 25

A. Logam Berat Pb Tersedia ................................................. 25

B. Logam Berat Cd Tersedia ................................................ 27

C. Logam Berat Cr Tersedia ..................................................... 30

D. Logam Berat Pb Total ........................................................ 33

E. Logam Berat Cd Total ...................................................... 36

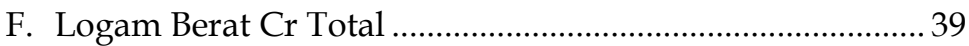

G. Logam Berat Cu Total .................................................. 42

H. Logam Berat Zn Total...................................................... 45 
BAB $\mathrm{V}$ KORELASI KANDUNGAN N TOTAL DAN PH TANAH DENGAN KANDUNGAN LOGAM BERAT ............49

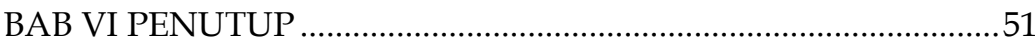

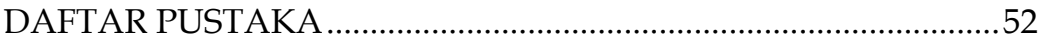




\section{IDENTIFIKASI LAHAN TERCEMAR LOGAM BERAT PADA TANAH SAWAH}




\section{BAB I \\ PENDAHULUAN}

\section{A. Penggunaan Lahan Sawah}

Tanah sawah merupakan tanah yang sangat penting di Indonesia karena merupakan sumber daya alam yang utama untuk membudidayakan tanaman padi dalam memproduksi beras. Padi (Oryza sativa L.) merupakan bahan makanan pokok utama untuk sebagian besar masyarakat Indonesia. Indonesia merupakan salah satu negara pengkonsumsi beras terbesar di dunia. Kebutuhan bahan makanan pokok utama ini terus meningkat akibat pertambahan jumlah penduduk tiap tahunnya terlebih lagi di Pulau Jawa, namun terdapat permasalahan dari jumlah kebutuhan yang terus menerus meningkat tiap tahunnya tetapi persediaan yang ada tidak dapat memenuhinya.

Salah satu permasalahan pada budidaya padi di lahan sawah adalah pencemaran tanah akibat adanya kawasan industri yang semakin berkembang. Salah satu pencemaran tanah akibat adanya kawasan industri yaitu pemcemaran logam berat dari limbah. Banyaknya limbah yang dihasilkan dari proses industri atau rumah tangga menyebabkan sumber air untuk pengairan mengalami pencemaran. Selanjutnya bahan yang terdiri dari senyawa beracun yang biasa disebut B3 (bahan berbahaya beracun) akan mengendap dalam tanah. Proses ini berulang dengan berjalannya waktu, sehingga terjadi akumulasi bahan tersebut berserta logam beratnya di dalam tanah. Akibatnya akan terjadi perubahan sifat fisik, kimia, dan biologi tanah yang tidak diinginkan terhadap tanah. Produktivitas tanah menurun, hal ini diikuti dengan kemampuan mendukung pertumbuhan tanaman menjadi turun. 


\section{B. Kandungan Logam Berat Lahan Sawah}

Logam berat merupakan unsur yang sulit untuk dirombak sehingga akan terakumulasi dan mengendap pada jaringan tubuh sehingga dapat menimbulkan keracunan bagi manusia, hewan, tanaman apabila keberadaannya melebihi ambang batas (Nurjaya dkk, 2006). Hal ini dikarenakan logam berat terserap ke dalam akar yang selanjutnya masuk ke dalam siklus rantai makanan, menyebabkan tingkat konsentrasi logam berat di dalam organisme menjadi tinggi, karena sifatnya yang sulit terurai dan terdeposit pada permukaan tanah sehingga dapat terserap oleh organisme. Proses ini dikenal sebagai biomagnifikasi. Proses biomagnifikasi ini dapat terjadi pada tanaman hasil panen seperti beras.

Salah satu upaya yang dapat dilakukan untuk memperbaiki produktivitas lahan sawah yaitu dengan penggunaan pupuk Nitrogen $(\mathrm{N})$ yang berimbang. $\mathrm{N}$ merupakan unsur hara makro utama yang sangat penting untuk pertumbuhan tanaman terutama untuk tanaman padi. Perlu diketahui bahwa sampai $70 \% \mathrm{~N}$ diambil dari tanah oleh tanaman padi serta hasil gabah sangat peka terhadap kelebihan dan kekurangan N. Fungsi N yaitu memperbaiki pertumbuhan vegetatif tanaman. Tanaman yang tumbuh pada tanah yang cukup $\mathrm{N}$, berwarna lebih hijau. $\mathrm{N}$ juga berfungsi sebagai pembentukan protein sedangkan gejalagejala yang ditimbulkan bila kekurangan $\mathrm{N}$ yaitu tanaman kerdil, pertumbuhan akar akan terbatas dan daun-daun kuning lalu gugur.

Identifikasi percemaran kandungan logam berat pada tanah sawah perlu dilakukan dengan cermat dan tepat agar dapat menentukan alternatif penanggulangannya yang sesuai dengan kebutuhan tanaman dan tingkat kesuburan tanah agar lebih efisien dan memperoleh hasil optimal, hal ini dapat dilakukan melalui survei tanah. Survei tanah adalah kegiatan pengamatan, pengukuran, analisis, dan klasifikasi sifat-sifat dan karakteristik tanah serta lingkungannya pada suatu 
hamparan lahan (wilayah) dengan tingkat ketelitian tertentu untuk suatu tujuan tertentu. Adapun tujuan survei tanah itu sendiri adalah untuk memberikan atau menyediakan informasi bagi pengguna tanah, bentuk wilayah, dan keadaan lain yang perlu diperhatikan, maka dengan mengetahui karakter dari suatu (sifatnya) bisa dioptimalisasi fungsi dan penggunaanya (Hakim et al., 1986).

Di daerah Jawa Barat terdapat kecamatan yang mengalami pencemaran lahan karena kegiatan Industri, yaitu Kecamatan Rancaekek. Sejak tahun 1978, industri tekstil dikembangkan di sepanjang jalan raya Rancaekek-Cicalengka, sekitar terdapat lahan persawahan. Lahan persawahan di Kecamatan Rancaekek telah mengalami pencemaran oleh logam berat, yang dimana mengandung $(\mathrm{Cu}, \mathrm{Zn}, \mathrm{Pb}, \mathrm{Cd}$, dan $\mathrm{Cr}$ ). Pembuangan limbah industri tersebut dialirkan ke badan air sungai yang mengakibatkan penurunan produktivitas lahan sawah serta kualitas hasil tanaman, hal ini dikarenakan air sungai tersebut digunakan untuk sumber pengairan sawah. Menurut penelitian Sudirja (2012) lahan pertanian di Rancaekek yang terkena air limbah tekstil akan tercemar oleh logam berat yang berpotensi membahayakan. Hal tersebut yang menjadikan daerah ini sebagai daerah penelitian yang dipusatkan pada sungai Cikijing dikarenakan sungai tersebut yang mendapatkan dampak paling besar tercemar limbah langsung dari pabrik industri tekstil, sungai Cikijing mengaliri lahan persawahan diempat desa yaitu desa Linggar, desa Jalenggong, desa Bojongloa dan desa Sukamulya.

\section{Metode Analisis}

\section{Tempat dan Waktu}

Penelitian yang ada dalam buku ini dilaksanakan pada lahan sawah yang tercemar logam berat dari limbah pabrik tekstil dari pengairan sungai Cikijing yaitu di Desa Jelekong, Desa Linggar, Desa Bojongloa, dan Desa 
Sukamulya Kecamatan Rancaekek (Gambar 1). Analisis sampel tanah dilakukan di Laboratorium Kesuburan Tanah dan Nutrisi Tanaman Fakultas Pertanian Universitas Padjadjaran. Dilaksanakan pada bulan Februari 2017 sampai dengan November 2017, meliputi tahap : persiapan, pengumpulan data, pengecekan lapangan, analisis dan penulisan laporan.

\section{Bahan dan Alat}

Bahan yang digunakan untuk survei dan pemetaan meliputi: peta tematik RT RW Kecamatan Rancaekek yang meliputi peta kemiringan lereng, peta jenis tanah, peta penggunaan lahan, peta administrasi, kertas A3 (untuk mencetak peta), sampel tanah tercemar logam berat dan bahan untuk analisis sampel tanah di laboratorium.

Alat yang digunakan mencangkup alat-alat pembuatan peta, survei tanah dan analisis tanah di laboratorium. Alat untuk pembuatan peta yang digunakan yaitu PC (Komputer), Software GIS (Arc GIS 10.1) dan printer warna, alat untuk survei meliputi : altimeter, gps, pisau lapang, bor tanah, plastik sampel, alat tulis dan label serta alat-alat yang digunakan untuk analisis sampel tanah di laboratorium.

\section{Metode}

\section{a. Rancangan Penelitian}

Penelitian dalam buku ini dilakukan dengan metode survei, pada tingkat ketelitian tinjau mendalam (semi detail) dengan skala peta $1: 25.000$. Penentuan titik sampel dilakukan berdasarkan Peta Satuan Lahan Homogen (SLH), yang dibuat dengan cara menumpangsusunkan peta (overlay) dari peta administrasi, peta jenis tanah, peta kelerengan dan peta penggunaan lahan daerah yang dianalisis. Sumber peta adalah peta tematik RT RW Kecamatan Rancaekek. Berdasarkan tata cara tersebut dipakai 1 kelas satuan 
lahan homogen yang terdapat pada Gambar 1. Berdasarkan tingkat ketelitian peta yang diuji, maka 25 Ha lahan sawah diwakili oleh 1 sampel pengamatan. Berdasarkan kalkulasi peta SLH diperoleh 50 titik sampel pengamatan. Pengambilan sampel tanah dilakukan dengan menggunakan bor tanah.. Sebaran titik sampel yang didapatkan dari peta SLH disajikan pada Tabel 1.
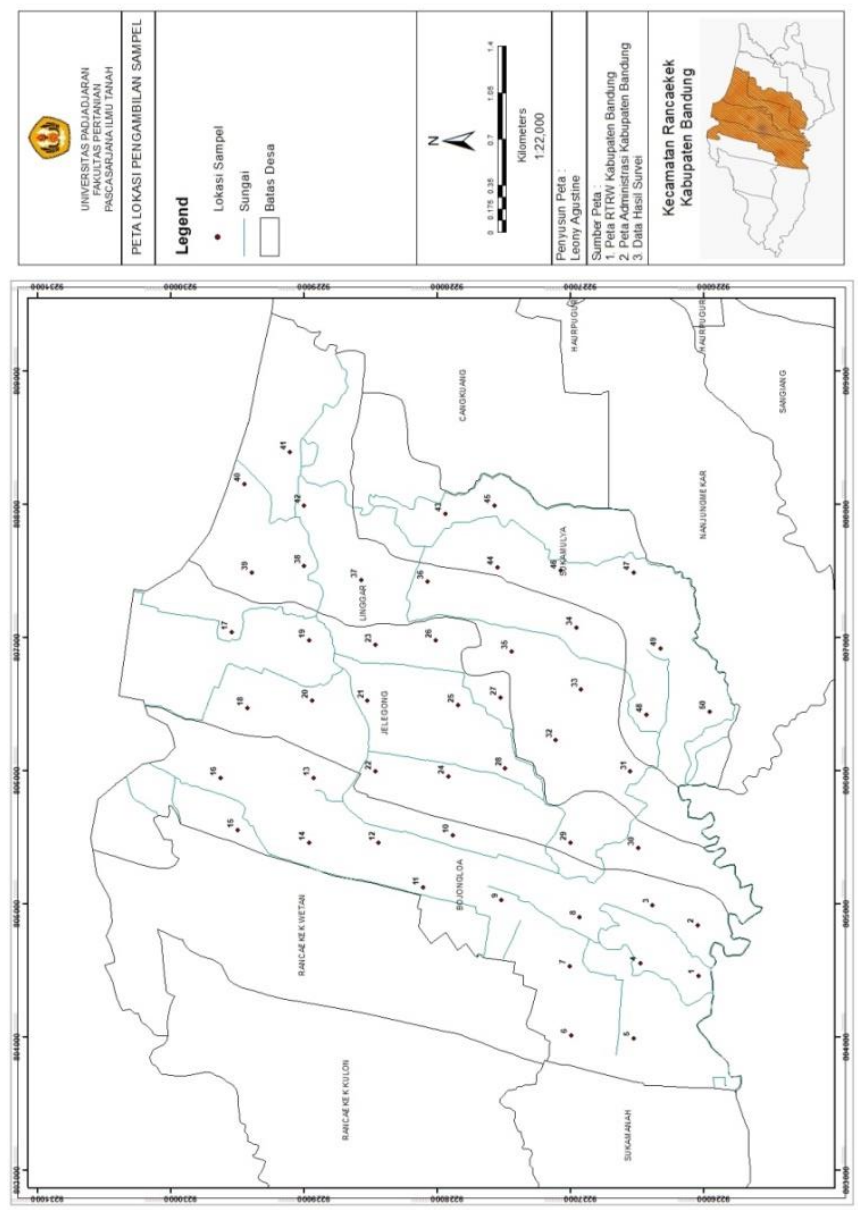

Gambar 1. Peta Lokasi Pengambilan Sampel 
Tabel 1. Sebaran Titik Sampel

\begin{tabular}{|c|c|c|c|c|}
\hline $\begin{array}{c}\text { Titik } \\
\text { Sampel } \\
\end{array}$ & Jenis Tanah & Kelerengan & Desa & $\begin{array}{c}\text { Koordinat } \\
\text { Titik Sampel }\end{array}$ \\
\hline 1 & Iceptisol & $<8 \%$ & Bojongloa & $\begin{array}{c}6^{\circ} 59^{\prime} 37.99^{\prime \prime} \mathrm{LS} \\
107^{\circ} 45^{\prime} 19.79^{\prime \prime} \mathrm{BT}\end{array}$ \\
\hline 2 & Iceptisol & $<8 \%$ & Bojongloa & $\begin{array}{c}6^{\circ} 59^{\prime} 37.76 " \mathrm{LS} \\
107^{\circ} 45^{\prime} 31.93^{\prime \prime} \mathrm{BT} \\
\end{array}$ \\
\hline 3 & Iceptisol & $<8 \%$ & Bojongloa & $\begin{array}{c}6^{\circ} 59^{\prime} 26.54^{\prime \prime L S} \\
107^{\circ} 45^{\prime} 36.45^{\prime \prime} \mathrm{BT}\end{array}$ \\
\hline 4 & Iceptisol & $<8 \%$ & Bojongloa & $\begin{array}{c}6^{\circ} 59^{\prime} 23.47 " \mathrm{LS} \\
107^{\circ} 45^{\prime} 21.88^{\prime \prime} \mathrm{BT}\end{array}$ \\
\hline 5 & Iceptisol & $<8 \%$ & Bojongloa & $\begin{array}{c}6^{\circ} 59^{\prime} 22.14^{\prime \prime} \mathrm{LS} \\
107^{\circ} 45^{\prime} 3.90^{\prime \prime} \mathrm{BT}\end{array}$ \\
\hline 6 & Iceptisol & $<8 \%$ & Bojongloa & $\begin{array}{c}6^{\circ} 59^{\prime} 7.01^{\prime \prime L S} \\
107^{\circ} 45^{\prime} 4.63^{\prime \prime} \mathrm{BT}\end{array}$ \\
\hline 7 & Iceptisol & $<8 \%$ & Bojongloa & $\begin{array}{c}6^{\circ} 59^{\prime} 6.43 \text { "LS } \\
107^{\circ} 45^{\prime} 21.81^{\prime \prime} \mathrm{BT} \\
\end{array}$ \\
\hline 8 & Iceptisol & $<8 \%$ & Bojongloa & $\begin{array}{c}6^{\circ} 59^{\prime} 8.73 \text { "LS } \\
107^{\circ} 45^{\prime} 33.81^{\prime \prime B T} \\
\end{array}$ \\
\hline 9 & Iceptisol & $<8 \%$ & Bojongloa & $\begin{array}{c}6^{\circ} 58^{\prime} 49.16^{\prime \prime} \mathrm{LS} \\
107^{\circ} 45^{\prime} 38.12^{\prime \prime} \mathrm{BT}\end{array}$ \\
\hline 10 & Iceptisol & $<8 \%$ & Bojongloa & $\begin{array}{c}6^{\circ} 58^{\prime} 37.71 \text { "LS } \\
107^{\circ} 45^{\prime} 53.81^{\prime \prime B T}\end{array}$ \\
\hline 11 & Iceptisol & $<8 \%$ & Bojongloa & $\begin{array}{c}6^{\circ} 58^{\prime} 30.54 \text { "LS } \\
107^{\circ} 45^{\prime} 40.52^{\prime \prime} \mathrm{BT}\end{array}$ \\
\hline 12 & Iceptisol & $<8 \%$ & Bojongloa & $\begin{array}{c}6^{\circ} 58^{\prime} 19.61 " \mathrm{LS} \\
107^{\circ} 45^{\prime} 51.20^{\prime \prime} \mathrm{BT}\end{array}$ \\
\hline 13 & Iceptisol & $<8 \%$ & Bojongloa & $\begin{array}{c}6^{\circ} 58^{\prime} 3.90^{\prime \prime} \mathrm{LS} \\
107^{\circ} 46^{\prime} 7.19^{\prime \prime} \mathrm{BT} \\
\end{array}$ \\
\hline 14 & Iceptisol & $<8 \%$ & Bojongloa & $\begin{array}{c}6^{\circ} 58^{\prime} 2.72 \text { "LS } \\
107^{\circ} 45^{\prime} 51.42 \text { "BT }\end{array}$ \\
\hline 15 & Iceptisol & $<8 \%$ & Bojongloa & $\begin{array}{c}6^{\circ} 57^{\prime} 45.37^{\prime \prime} \mathrm{LS} \\
107^{\circ} 45^{\prime} 54.45^{\prime \prime} \mathrm{BT}\end{array}$ \\
\hline 16 & Iceptisol & $<8 \%$ & Bojongloa & $\begin{array}{c}6^{\circ} 57^{\prime} 40.90^{\prime \prime} \mathrm{LS} \\
107^{\circ} 466^{\prime} 7.22^{\prime \prime} \mathrm{BT}\end{array}$ \\
\hline 17 & Iceptisol & $<8 \%$ & Jalegong & $\begin{array}{c}6^{\circ} 57^{\prime} 43.53 \text { "LS } \\
107^{\circ} 46^{\prime} 42.58^{\prime \prime} \mathrm{BT}\end{array}$ \\
\hline 18 & Iceptisol & $<8 \%$ & Jalegong & $\begin{array}{c}6^{\circ} 57^{\prime} 47.41^{\prime \prime L S} \\
107^{\circ} 46^{\prime} 23.99^{\prime \prime} \mathrm{BT}\end{array}$ \\
\hline 19 & Iceptisol & $<8 \%$ & Jalegong & $\begin{array}{c}6^{\circ} 58^{\prime} 2.30^{\prime \prime L S} \\
107^{\circ} 46^{\prime} 41.10^{\prime \prime} \mathrm{BT}\end{array}$ \\
\hline 20 & Iceptisol & $<8 \%$ & Jalegong & $\begin{array}{c}6^{\circ} 58^{\prime} 3.33^{\prime \prime L S} \\
107^{\circ} 46^{\prime} 26.29^{\prime \prime} \mathrm{BT}\end{array}$ \\
\hline 21 & Iceptisol & $<8 \%$ & Jalegong & $\begin{array}{c}6^{\circ} 58^{\prime} 17.03^{\prime \prime} \mathrm{LS} \\
107^{\circ} 46^{\prime} 26.50^{\prime \prime} \mathrm{BT}\end{array}$ \\
\hline 22 & Iceptisol & $<8 \%$ & Jalegong & $\begin{array}{c}6^{\circ} 58^{\prime} 18.56^{\prime \prime} \mathrm{LS} \\
107^{\circ} 466^{\prime} 8.71^{\prime \prime} \mathrm{BT}\end{array}$ \\
\hline 23 & Iceptisol & $<8 \%$ & Jalegong & $\begin{array}{c}6^{\circ} 58^{\prime} 18.54 \text { "LS } \\
107^{\circ} 46^{\prime} 39.76 \text { "BT }\end{array}$ \\
\hline 24 & Iceptisol & $<8 \%$ & Jalegong & $\begin{array}{c}6^{\circ} 58^{\prime} 36.52^{\prime \prime L S} \\
107^{\circ} 46^{\prime} 7.87^{\prime \prime B T}\end{array}$ \\
\hline 25 & Iceptisol & $<8 \%$ & Jalegong & $\begin{array}{c}6^{\circ} 58 ' 38.80^{\prime \prime} \mathrm{LS} \\
107^{\circ} 46^{\prime} 25.23^{\prime \prime} \mathrm{BT}\end{array}$ \\
\hline 26 & Iceptisol & $<8 \%$ & Jalegong & $\begin{array}{c}6^{\circ} 58^{\prime} 33.17^{\prime \prime} \mathrm{LS} \\
107^{\circ} 46^{\prime} 41.28^{\prime \prime} \mathrm{BT} \\
\end{array}$ \\
\hline 27 & Iceptisol & $<8 \%$ & Jalegong & $\begin{array}{c}6^{\circ} 58^{\prime} 49.19^{\prime \prime} \mathrm{LS} \\
107^{\circ} 46^{\prime} 27.34^{\prime \prime B T} \\
\end{array}$ \\
\hline
\end{tabular}




\begin{tabular}{|c|c|c|c|c|}
\hline 28 & Iceptisol & $<8 \%$ & Jalegong & $\begin{array}{c}6^{\circ} 58^{\prime} 50.40^{\prime \prime} \mathrm{LS} \\
107^{\circ} 46^{\prime} 9.84^{\prime \prime} \mathrm{BT}\end{array}$ \\
\hline 29 & Iceptisol & $<8 \%$ & Jalegong & $\begin{array}{c}6^{\circ} 59^{\prime} 6.57^{\prime \prime} \mathrm{LS} \\
107^{\circ} 45^{\prime} 51.93 \text { "BT }\end{array}$ \\
\hline 30 & Iceptisol & $<8 \%$ & Jalegong & $\begin{array}{c}6^{\circ} 59^{\prime} 23.14 \text { "LS } \\
107^{\circ} 45^{\prime} 50.92^{\prime \prime} \mathrm{BT}\end{array}$ \\
\hline 31 & Iceptisol & $<8 \%$ & Linggar & $\begin{array}{c}6^{\circ} 59^{\prime} 3.03^{\prime \prime} \mathrm{LS} \\
107^{\circ} 46^{\prime} 9.13^{\prime \prime} \mathrm{BT}\end{array}$ \\
\hline 32 & Iceptisol & $<8 \%$ & Linggar & $\begin{array}{c}6^{\circ} 59^{\prime} 2.98^{\prime \prime} \mathrm{LS} \\
107^{\circ} 46^{\prime} 17.01 " \mathrm{BT}\end{array}$ \\
\hline 33 & Iceptisol & $<8 \%$ & Linggar & $\begin{array}{c}6^{\circ} 59^{\prime} 8.89 \text { "LS } \\
107^{\circ} 46 \text { '29.51"BT }\end{array}$ \\
\hline 34 & Iceptisol & $<8 \%$ & Linggar & $\begin{array}{c}6^{\circ} 59^{\prime} 7.70^{\prime \prime L S} \\
107^{\circ} 46^{\prime} 44.15 " \mathrm{BT}\end{array}$ \\
\hline 35 & Iceptisol & $<8 \%$ & Linggar & $\begin{array}{c}6^{\circ} 58^{\prime} 51.96^{\prime \prime} \mathrm{LS} \\
107^{\circ} 466^{\prime} 38.56 " \mathrm{BT}\end{array}$ \\
\hline 36 & Iceptisol & $<8 \%$ & Linggar & $\begin{array}{c}6^{\circ} 58^{\prime} 31.20^{\prime \prime} \mathrm{LS} \\
107^{\circ} 46^{\prime} 55.30^{\prime \prime} \mathrm{BT}\end{array}$ \\
\hline 37 & Iceptisol & $<8 \%$ & Linggar & $\begin{array}{c}6^{\circ} 58^{\prime} 14.80^{\prime \prime} \mathrm{LS} \\
107^{\circ} 46^{\prime} 55.86 " \mathrm{BT}\end{array}$ \\
\hline 38 & Iceptisol & $<8 \%$ & Linggar & $\begin{array}{c}6^{\circ} 58^{\prime} 0.93^{\prime \prime L S} \\
107^{\circ} 46^{\prime} 58.77^{\prime \prime} \mathrm{BT}\end{array}$ \\
\hline 39 & Iceptisol & $<8 \%$ & Linggar & $\begin{array}{c}6^{\circ} 57^{\prime} 48.32 \text { "LS } \\
107^{\circ} 466^{\prime} 57.42 " \mathrm{BT}\end{array}$ \\
\hline 40 & Iceptisol & $<8 \%$ & Linggar & $\begin{array}{c}6^{\circ} 57^{\prime} 46.30^{\prime \prime} \mathrm{LS} \\
107^{\circ} 47^{\prime} 19.03^{\prime \prime B T}\end{array}$ \\
\hline 41 & Iceptisol & $<8 \%$ & Linggar & $\begin{array}{c}6^{\circ} 57^{\prime} 57.12^{\prime \prime} \mathrm{LS} \\
107^{\circ} 477^{\prime} 26.81^{\prime \prime B T}\end{array}$ \\
\hline 42 & Iceptisol & $<8 \%$ & Linggar & $\begin{array}{c}6^{\circ} 58^{\prime} 1.00^{\prime \prime L S} \\
107^{\circ} 47^{\prime} 14.07 " \mathrm{BT}\end{array}$ \\
\hline 43 & Iceptisol & $<8 \%$ & Sukamulya & $\begin{array}{c}6^{\circ} 58^{\prime} 35.36^{\prime \prime} \mathrm{LS} \\
107^{\circ} 47^{\prime} 12.06 " \mathrm{BT}\end{array}$ \\
\hline 44 & Iceptisol & $<8 \%$ & Sukamulya & $\begin{array}{c}6^{\circ} 58^{\prime} 48.06^{\prime \prime} \mathrm{LS} \\
107^{\circ} 466^{\prime} 59.05^{\prime \prime} \mathrm{BT}\end{array}$ \\
\hline 45 & Iceptisol & $<8 \%$ & Sukamulya & $\begin{array}{c}6^{\circ} 58^{\prime} 47.19^{\prime \prime} \mathrm{LS} \\
107^{\circ} 47^{\prime} 14.18^{\prime \prime} \mathrm{BT}\end{array}$ \\
\hline 46 & Iceptisol & $<8 \%$ & Sukamulya & $\begin{array}{c}6^{\circ} 59^{\prime} 4.14^{\prime \prime} \mathrm{LS} \\
107^{\circ} 46^{\prime} 58.20^{\prime \prime} \mathrm{BT}\end{array}$ \\
\hline 47 & Iceptisol & $<8 \%$ & Sukamulya & $\begin{array}{c}6^{\circ} 59^{\prime} 21.64 " \mathrm{LS} \\
107^{\circ} 46^{\prime} 57.98^{\prime \prime} \mathrm{BT}\end{array}$ \\
\hline 48 & Iceptisol & $<8 \%$ & Sukamulya & $\begin{array}{c}6^{\circ} 59^{\prime} 24.83^{\prime \prime} \mathrm{LS} \\
107^{\circ} 46^{\prime} 23.45^{\prime \prime} \mathrm{BT}\end{array}$ \\
\hline 49 & Iceptisol & $<8 \%$ & Sukamulya & $\begin{array}{c}6^{\circ} 59^{\prime} 28.22^{\prime \prime} \mathrm{LS} \\
107^{\circ} 46^{\prime} 39.23^{\prime \prime} \mathrm{BT}\end{array}$ \\
\hline 50 & Iceptisol & $<8 \%$ & Sukamulya & $\begin{array}{c}6^{\circ} 59^{\prime} 40.12^{\prime \prime} \mathrm{LS} \\
107^{\circ} 45^{\prime} 19.54 \text { "BT }\end{array}$ \\
\hline
\end{tabular}

Dari data tabel diatas maka dapat disimpulkan tanah sawah di Kecamatan Rancaekek hanya memiliki satu kelas satuan lahan homogen, hal ini dikarenakan tanah sawah di Kecamatan Rancaekek hanya memiliki satu jenis tanah dan satu jenis kelerengan. 


\section{b. Rancangan Analisis}

Model rancangan analisis yang digunakan adalah data lapangan yang diperoleh berdasarkan hasil pengamatan di lapangan dan data yang didapatkan melalui wawancara dengan petani serta data analisis sampel tanah yang tercemar logam berat di laboratorium, semua dikelompokkan dan disusun dalam tabel hasil status kandungan logam berat. Nilai hasil analisis dikelompokkan berdasarkan kriteria penilaian hasil analisis tanah menurut Balai Penelitian Tanah 2005 dan Alloway (1995), selanjutnya data tersebut di kelompokkan berdasarkan kesamaan kriteria nilai status kandungan logam berat menjadi satu kelas ke dalam peta dengan menggunakan aplikasi SIG (Arc GIS 10.1).

\section{c. Rancangan Respon}

Pengamatan yang dilakukan terdiri dari pengamatan penunjang dan pengamatan utama.

Pengamatan penunjang terdiri dari :

1) N Total

2) $\mathrm{pH}$ tanah

3) C-Organik

Pengamatan utama terdiri dari :

1) Logam Berat $(\mathrm{Pb}, \mathrm{Cd}, \mathrm{Cr}, \mathrm{Cu}$ dan $\mathrm{Zn})$

2) Logam Tersedia $(\mathrm{Pb}, \mathrm{Cd}$ dan $\mathrm{Cr})$

\section{Pelaksanaan}

\section{a. Pembuatan Peta SLH dan Lokasi Titik Sampel}

Pembuatan peta Satuan Lahan Homogen (SLH) dan titik lokasi sampel didapat dengan menggunakan aplikasi Arc GIS 10.1 yang dibuat dengan cara menumpangsusunkan peta (overlay) dari peta administrasi, peta jenis tanah, peta kelerengan dan peta penggunaan lahan, pada peta penggunaan lahan dapat ditentukan titik lokasi sampel dari penggunaan luas lahan sawah. Luas penggunaan lahan sawah pada peta 
yaitu sebesar 425 Ha pada Desa Bojongloa, 378 Ha pada Desa Jalegong, 311 Ha pada Desa Linggar dan 245 Ha pada Desa Sukamulya, maka dari data luas penggunaan lahan sawah didapatkan 50 titik sampel pada peta satuan lahan homogen.

b. Survei dan Pengambilan Sampel Tanah

Tahap survei merupakan tahap pengamatan lapang sesuai dengan penetapan pada peta SLH lokasi setiap titik sampel tanah sawah di Kecamatan Rancaekek yang sudah dikoordinatkan, pada setiap lokasi titik sampel dilakukan pengambilan sampel tanah untuk dianalisis di laboratorium dan pengambilan tanah untuk pengaplikasian alternatif penanggulangan logam berat pada tanah tersebut.

c. Analisis Sampel Tanah

Pengambilan sampel tanah untuk analisis tanah di laboratorium yaitu sampel tanah yang diambil di lapangan pada kedalaman $0-30 \mathrm{~cm}$ dari lima titik yang berbeda kemudian disatukan secara komposit lalu timbang sebanyak 500 g. Analisis tanah berupa kandungan logam berat $(\mathrm{Pb}, \mathrm{Cd}, \mathrm{Cr}, \mathrm{Cu}$ dan $\mathrm{Zn}), \mathrm{N}$ total, C-organik dan $\mathrm{pH}$ tanah.

\section{d. Korelasi Logam Berat, Unsur Hara N dan pH Tanah}

Hasil analisis sampel tanah yang didapatkan kemudian diolah dan di korelasikan menurut kandungan logam berat $(\mathrm{Pb}, \mathrm{Cd}, \mathrm{Cr}, \mathrm{Cu}$ dan $\mathrm{Zn})$ terhadap unsur hara $\mathrm{N}$ total, kandungan logam berat $(\mathrm{Pb}, \mathrm{Cd}, \mathrm{Cr}, \mathrm{Cu}$ dan $\mathrm{Zn})$ terhadap $\mathrm{pH}$ tanah dan kandungan logam berat $(\mathrm{Pb}, \mathrm{Cd}, \mathrm{Cr}, \mathrm{Cu}$ dan $\mathrm{Zn})$ terhadap C-organik. 


\section{BAB II \\ DESKRIPSI LAHAN SAWAH}

\section{A. Jenis Tanah}

Jenis tanah di wilayah terdapat 1 (satu) jenis tanah yaitu Inceptisols (Gambar 3). Inceptisols adalah tanah yang belum matang dengan perkembangan profil yang lebih lemah dibanding dengan tanah yang matang dan masih memiliki sifat yang menyerupai sifat bahan induknya (Hardjowigeno, 1993). Tanah Inceptisols yang terdapat di dataran rendah, solum yang terbentuk pada umumnya tebal, sedangkan pada daerah-daerah berlereng curam solum yang terbentuk akan tipis. Warna tanah Inceptisosl beranekaragam tergantung dari jenis bahan induknya. Warna kelabu bahan induknya dari endapan sungai, warna coklat kemerah-merahan karena mengalami proses reduksi, warna hitam mengandung bahan organik yang tinggi.

Karakteristik tanah Inceptisol memiliki tekstur pasir, debu, dan lempung, struktur tanah remah konsistensi gembur, $\mathrm{pH} 5,0$ sampai 7,0, bahan organik cukup tinggi (10\% sampai 31\%), kandungan unsur hara yang sedang sampai tinggi, produktivitas tanahnya sedang sampai tinggi (Nuryani $\mathrm{dkk}$, 2003). Inceptisols yang dijumpai pada tanah-tanah sawah memerlukan masukan yang tinggi dari bahan an-organik seperti pemupukan $\mathrm{N}, \mathrm{P}, \mathrm{K}$ dan masukan bahan organik seperti percampuran sisa-sisa panen ke dalam tanah saat pengolahan tanah, serta pemberian pupuk kandang terutama bila lahan dipersiapkan untuk tanaman palawija setelah padi (Munir, 1996). 

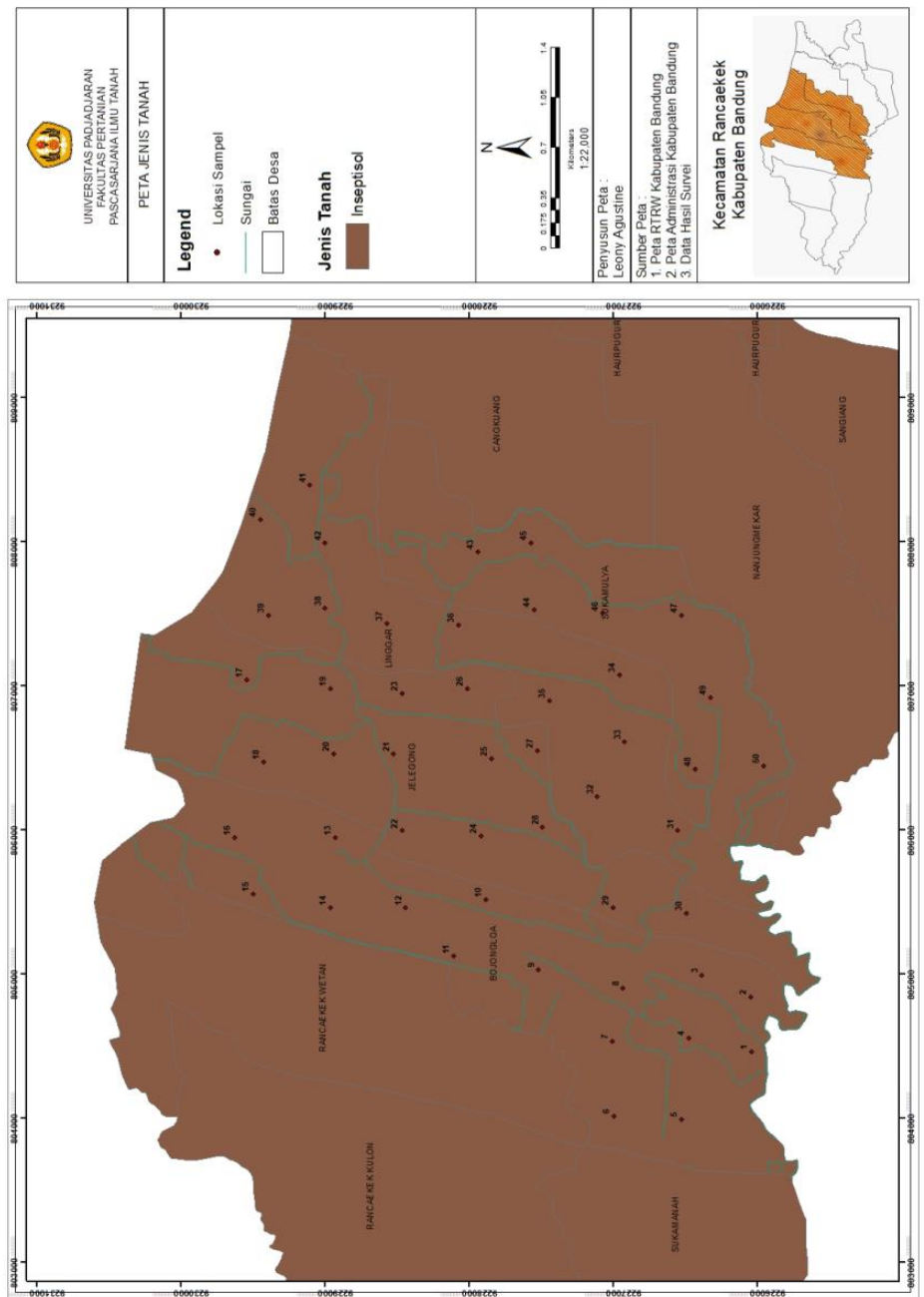

Gambar 2. Peta Jenis Tanah

\section{B. Topografi}

Wilayah tanah sawah di Kecamatan Rancaekek memiliki tingkat kemiringan lereng $<8 \%$ yang tergolong dalam kelas datar (Gambar 4). Kondisi lereng yang semakin curam mengakibatkan pengaruh gaya berat dalam memindahkan bahan-bahan yang terlepas meninggalkan lereng semakin besar pula. Jika proses tersebut terjadi pada kemiringan lereng lebih dari $8 \%$, maka aliran permukaan 
akan semakin meningkat dalam jumlah dan kecepatan seiring dengan semakin curamnya lereng. Berdasarkan hal tersebut, diduga penurunan sifat fisik tanah akan lebih besar terjadi pada lereng $30-45 \%$. Hal ini disebabkan pada daerah yang berlereng curam (30-45\%) terjadi erosi terus menerus sehingga tanah-tanahnya bersolum dangkal, kandungan bahan organik rendah, tingkat kepadatan tanah yang tinggi, serta porositas tanah yang rendah dibandingkan dengan tanah-tanah di daerah datar yang air tanahnya dalam. Perbedaan lereng juga menyebabkan perbedaan banyaknya air tersedia bagi tumbuh-tumbuhan sehingga mempengaruhi pertumbuhan vegetasi di tempat tersebut (Hardjowigeno, 1993). 

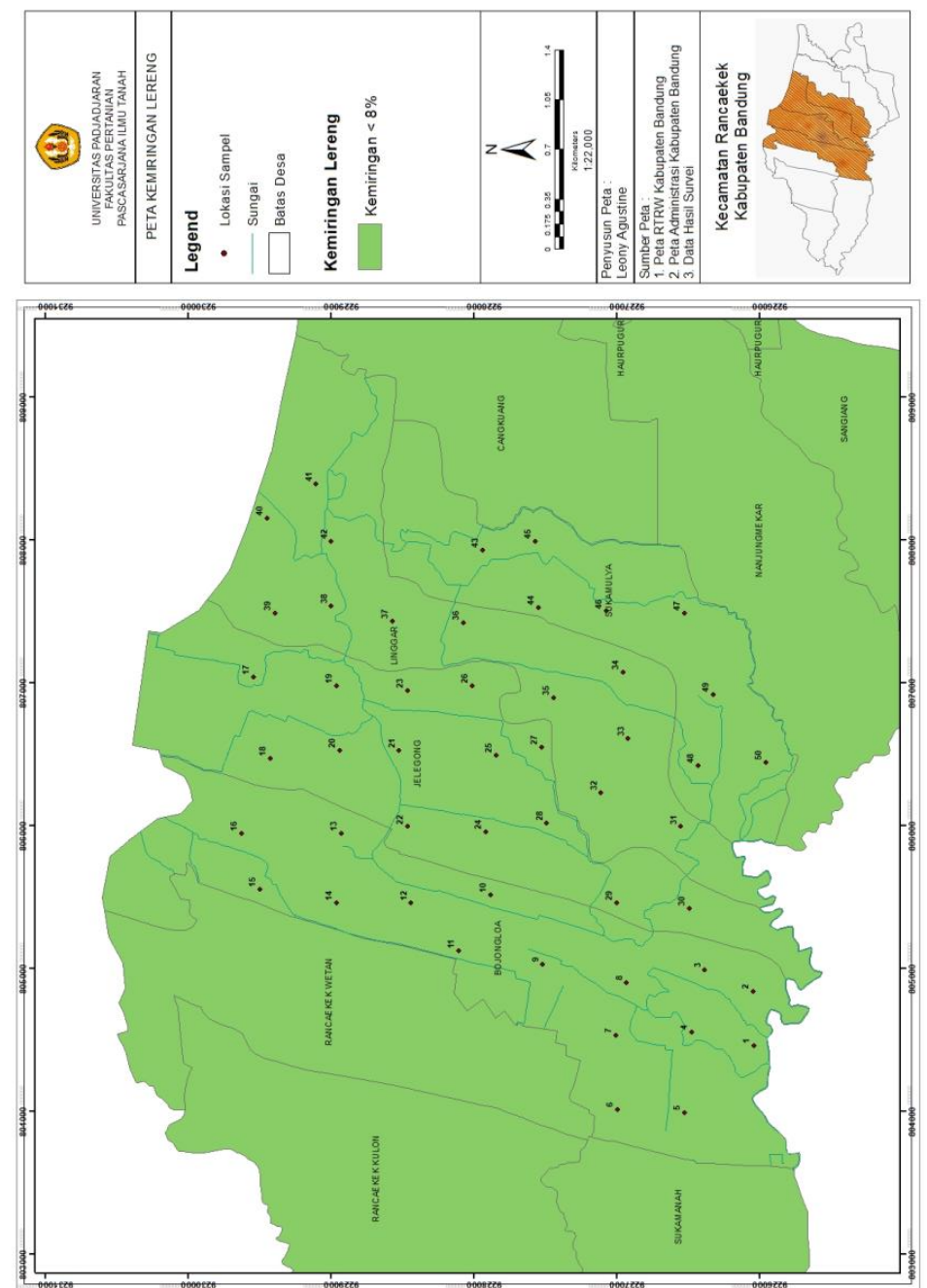

Gambar 3. Peta Kemiringan Lereng

\section{Penggunaan Lahan}

Luas wilayah (Ha) menurut penggunaan lahannya secara keseluruhan disajikan dalam Tabel 2. Kondisi penggunaan lahan pada Kecamatan Rancaekek pada tabel dibawah ini menunjukkan bahwa penggunaan lahan sawah lebih mendominasi dari jumlah secara keseluruhan penggunaan lahan di Kecamatan tersebut (Gambar 4). 